\title{
ANALISIS GANGGUAN BERBAHASA PADA ANAK DI KECAMATAN PAHAE JULU
}

\author{
Monika Sitompul \\ Universitas Sumatera Utara \\ e-mail: monika@gmail.com
}

\begin{abstract}
Abstrak
Penelitian ini berawal dari kasus gangguan bahasa yang terjadi di masyarakat di Kabupaten Pahae Julu. Bahasa adalah kebutuhan untuk berinteraksi, dan manusia telah diberkati dengan Perangkat Akuisisi Bahasa (LAD) atau bahasa apa pun oleh dewa. Namun, jika ketika berbicara tentang seseorang yang mengalami gangguan pada LAD dan bagian pemrosesan bahasa otak, maka komunikasi tidak akan lancar. Gangguan bahasa bisa terjadi pada siapa saja. Tujuan dari penelitian ini adalah untuk mengungkap beberapa jenis gangguan bahasa, kasus gangguan bahasa dan untuk mengetahui penyebab gangguan bahasa yang dialami oleh masyarakat di Pahae Julu. Metode yang digunakan dalam penelitian ini adalah metode penelitian deskriptif jenis studi kasus.
\end{abstract}

Kata Kunci: gangguan berbahasa,kecamatan Pahae Julu, jenis, kasus, penyebab, penanganan.

\section{Abstract}

This study originated from cases of language disorders that occur in society in Pahae Julu district. Language is a need to interact, and humans have been blessed with Language Acquisition Device (LAD) or any language by god. However, if when speaking of someone impaired both LAD and language processing part of the brain, then the communication will not be smooth. The language disorders can happen to anyone. The purpose of this study is to reveal some kinds of language disorders, cases of language disorders and to find out the causes of language disorders experienced by the community in Pahae Julu. The method used in this research is descriptive research method type of case studies.

Key Words: language disorders, Pahae Julu sub-district, types, cases, causes, treatment..

\section{PENDAhuluan}

Bahasa adalah alat komunikasi antara anggota masyarakat berupa simbol bunyi yang dihasilkan oleh alat ucap manusia. Berbahasa merupakan proses mengkomunikasikan bahasa tersebut. Proses berbahasa sendiri memerlukan pikiran dan perasaan yang dilakukan oleh otak manusia untuk menghasilkan kata-kata atau kalimat. Secara teoritis proses berbahasa dimulai dengan enkode semantik, enkode gramatika dan enkode fonologi. Enkode semantik dan enkode gramatika berlangsung dalam otak, sedangkan enkode fonologi dimulai dari otak lalu diteruskan pelaksanaannya oleh alat-alat bicara yang melibatkan sistem syaraf otak bicara. Ketiga enkode tersebut berkaitan dalam kegiatan produksi bahasa seseorang yang juga berkaitan erat dengan hubungan antara otak dan organ bicara seseorang.
Berbahasa merupakan sebuah kebutuhan yang tidak bisa ditinggalkan oleh manusia, karena berbahasa merupakan kegiatan yang hanya bisa dilakukan oleh manusia. Pada hakikatnya berbahasa merupakan suatu kegiatan alamiah yang sama halnya dengan bernapas yang kita tidak memikirkannya. Akan tetapi, bila kita pikirkan seandainya kita tidak berbahasa, dan kita tidak melakukan tindak berbahasa, maka identitas kita sebagai "genus manusia" (homosapiens) akan hilang karena bahasa mencerminkan "kemanusiaan". Yang paling membedakan kita dari makhluk lain ialah bahwa kita mempunyai bahasa (Indah,2017:4).

Dalam hal ini tentunya merupakan kerugian yang sangat besar apabila manusia tidak dapat berbahasa dengan baik, karena manusia telah dikarunia Language Acquisition Device (LAD) atau piranti kebahasaan oleh sang pencipta. Apabila kita berbicara mengenai LAD maka, 
kita berbicara mengenai teori nativisme yang dipelopori Chomsky. Setiap manusia memiliki bakat untuk berbahasa. Pendapat ini bertentangan dengan teori behaviorisme Watson yang mengatakan bahwa manusia dapat berbahasa akibat adanya stimulus dan respon (Simanjuntak, 1987:160). Namun kalau kita amati dengan saksama kita akan dapat memadukan kedua teori tersebut dalam berbahasa. Ada seseorang yang memiliki bakat untuk mengembangan bahasa artinya memiliki piranti kebahasaan yang lengkap, namun tidak ada stimulus dan respon berupa bahasa, maka seseorang tersebut akan memiliki gangguan berbahasa.

Menurut Natsir (2017:22) bahwa pembelajaran bahasa, sebagai salah satu masalah kompleks manusia, kegiatan berbahasa itu bukan hanya berlangsung secara mekanistik, tetapi juga berlangsung secara mentalistik. Artinya, kegiatan berbahasa itu berkaitan juga dengan proses atau kegiatan mental (otak). Manusia yang normal fungsi otak dan alat bicaranya tentu dapat berbahasa dengan baik. Namun, mereka yang memiliki kelainan fungsi otak dan alat bicaranya, tentu mempunyai kesulitan dalam berbahasa, baik produktif maupun reseptif. Jadi, kemampuan berbahasa terganggu.

Gangguan-gangguan berbahasa tersebut sebenarnya akan sangat mempengaruhi proses berkomunikasi dan berbahasa. Seorang anak yang dilahirkan di keluarga normal, dan dibesarkan di lingkungan yang normal pula, mungkin saja anak tersebut tidak bisa berbahasa. Walaupun seorang anak mendapatkan stimulus yang bagus, namun apabila piranti kebahasaannya kurang sempurna maka anak tersebut akan mengalami kesulitan berbahasa. Oleh karena itu, dalam kaitannya dengan pembelajaran dan gangguan berbahasa, studi linguistik perlu dilengkapi dengan studi antar disiplin antara linguistik dan psikologi, yang lazim disebut psikolinguistik. Bahasan mengenai pemerolehan bahasa berkaitan erat dengan bagaimana manusia dapat mempersepsi dan kemudian memahami ujaran orang lain. Maka dari itu penulis merumuskan beberapa masalah diantaranya apa sajakah jenis-jenis gangguan berbahasa pada anak di kecamatan Pahae Julu dan bagaimanakah cara penanganan gangguan berbahasa pada anak tersebut.

Metode pengumpulan data yang digunakan dalam penelitian ini adalah dengan menggunakan Observasi langsung. Data terdiri dari 2 yaitu, data primer dan data sekunder. Data primer adalah data yang diambil langsung dari responden melalui beberapa tahapan obeservasi sedangkan data sekunder adalah data pendukung yang diperoleh dari orang-orang terdekat responden yang diteliti. Analisis Data Setelah dilakukan pengumpulan data secara manual selanjutnya data diolah dengan bantuan kom-puterisasi menggunakan uji statistic.

\section{PEMBAHASAN}

Beberapa jenis gangguan berbahasa dapat terdeteksi sejak masa kanak-kanak di kecamatan Pahae Julu. Diantaranya yaitu spektrum autisme, apraksia lisan, disleksia, gagap, keterlambatan berbicara (speech delay) dan cerebral palsy. Spektrum Autisme atau Autism Spectrum Disorder (ASD) diambil dari istilah Schizoprenia yaitu Bleuler yang mengindikasikan gejala berupa kehidupan dalam dunia sendiri tanpa menghiraukan dunia luar. Secara umum pada penyandang autisme terdapat problem neurologis yang mempengaruhi pikiran, persepsi dan perhatiannya yang lalu merambat mempengaruhi perilaku. Dalam etape berikutnya, simtom yang ada akan menghambat dan mengganggu signal pancaindera, sampai membatasi perkembangan anak dalam berkomunikasi, berinteraksi, serta berimajinasi.

Kemampuan anak yang terkena sindrom ini terhadap lingkungan dan sosioempirik pun melemah atau bahkan nyaris tidak ada sama sekali. Anak autis selain tidak responsif terhadap orang lain juga terobsesi dengan kesamaan lingkungan. Artinya, dia sangat kaku dengan rutinitas yang dihadapinya, dia 
akan marah apabila terdapat perubahan kondisi dari yang biasa dijumpainya. Ada dua kategori perilaku autisme yaitu perilaku eksesif (berlebihan) dan perilaku defisit (berkekurangan). Yang termasuk perilaku eksesif yaitu hiperaktif dan tantrum (mengamuk) berupa jeritan, menyepak, menggigit, mencakar, memukul, dsb. Disini juga sering terjadi anak menyakiti diri sendiri (self-abuse). Perilaku defisit ditandai dengan gangguan bicara, perilaku sosial kurang sesuai (naik ke pangkuan ibu bukan untuk kasih sayang tapi untuk meraih kue), defisit sensoris sehingga dikira tuli, bermain tidak benar dan emosi yang tidak tepat, misalnya tertawa tanpa sebab, menangis tanpa sebab, dan melamun (Handoyo, 2004).

Contoh simtom yang mencirikan autisme diantaranya yaitu: tidak mau melakukan kontak mata; tidak mau berinteraksi; keterbatasan komunikasi; lamban belajar bahasa, hiperaktif; berjalan menjinjit atau berputar-putar; stimulasi diri; suka menggeleng-gelengkan kepala; sensitif terhadap suara tertentu; gangguan metabolisme atau pencernaan dan pola tidur; suka berteriak-teriak sendiri; sering berbicara, tertawa atau menangis sendiri tanpa sebab yang jelas; menggigit-gigit pensil, rambut, kuku, mainan, tepi jilbab atau pakaian; suka memerawang; suka melihat benda yang kecil; ketika mengangkat atau mengambil suatu benda, matanya selalu mendekatinya; menyusun benda secara berbaris, suka menciumi benda, tidak bisa duduk diam; tidak bisa mengkordinasi gerakan sendiri; sering melakukan gerakan yang menggunakan tenaga kuat misalnya berlari-lari, menepuk tangan dengan keras; dan lain sebagainya.

Pada kasus autisme terjadi kombinasi antara kelainan kognitif dan sosial. Penyandang autisme bisa jadi membisu hingga usia lima tahun, atau hanya membeo kata-kata orang dewasa yang didengarnya. Hal ini mengindikasikan bahwa penyandang autisme memiliki keterbatasan alam pikir, artinya mereka tidak mampu memahami dunia dari sudut pandang orang lain. Segala aspek komunikasi sulit dicapai penyandang autisme, kecuali aspek fonologis yang pada sebagian penyandang tetap dapat dikuasai. Perkembangan keterampilan bahasanya tidak saja mengalami keterlambatan tetapi juga penyimpangan.

Apraksia lisan merupakan gangguan motorik wicara yang dapat terjadi pada berbagai usia. Anak dengan apraksia lisan mengalami kesulitan merencanakan dan menghasilkan urutan gerak organ wicara yang tepat dan sesuai untuk ekspresi yang dapat dipahami lawan bicara. Apraksia lisan memiliki beberapa tingkatan, ringan, sedang dan berat. Hambatannya adalah menggerakkan motorik organ wicara seperti lidah, bibir, lahang, dan langit-langit lunak karena kesulitan dalam pemrograman bahasa di otak.

Tindak tutur berawal dari hasrat berkomunikasi. Kemudian terbentuk sebagai garis besar keinginan yang akan disampaikan. Ujaran pesan lalu dirangkai sesuai kaidah gramatika. Ujaran yang terdiri dari rangkaian bunyi atau fonem dan suku kata tersebut diterjemahkan menjadi informasi bunyi untuk diolah melalui gerakan motorik lidah, bibir, lahang, dan langit-langit lunak. Otot pada organ wicara diatur oleh otak sehingga artikulasinya sesuai. Dalam hal ini diperlukan kekuatan dan kelenturan otot wicara yang diperoleh dengan belajar dari pengalaman. Semakin banyak kata atau ujaran diulang, semakin otomatis gerak motorik wicara terjadi. Proses merancang dan menghasilkan ujaran makin mudah karena terprogram di otak dan dapat diakses dengan cepat manakala dibutuhkan. Disinilah letak aspek kesulitan pada anak-anak penyandang apraksia lisan. Akses informasi ke otak untuk merancang ujaran dan menghasilkan tutur terhambat karena sebab tertentu.

Beberapa karakteristik anak penderita apraksi lisan yaitu 1)Anak tidak mengucapkan kata, kosakata sedikit antara 100-200 kata. Ujaran maksimal terdiri dari kombinasi dua kata, 2)Anak menunjukkan kesulitan mengucapkan kata, sedikit mencoba berbicara tapi mudah frustasi. 3)Anak menggunakan 
isyarat atau gesture untuk berkomunikasi, termasuk menggunakan ekspresi wajah dan gerak tubuh. Cenderung menirukan bunyi (suara mobil, mesin, binatang, dll), 4)Pengucapan tidak konsisten. Contoh: kata 'me' diucapkan bervariasi 'bee', 'nee','dee'; pengucapan fonem yang benar pada satu kata tetapi tidak dapat digunakan pada kata lain. Contoh: fonem /p/ diucapkan dengan benar pada kata 'poppy' tapi ketika melafalkan kata 'happy' diucapkan 'huh-ee'; ketika diminta menirukan kata, anak tampak ragu dan sulit memulai dan terdapat tutur anak dengan intonasi dan pola penekanan yang aneh, banyak jeda.

Disleksia adalah kelainan proses belajar yang khusus terjadi di bidang kemampuan membaca, menulis dan mengeja. Kesulitan ini disebabkan oleh masalah untuk mengenali bunyi perkataan dan bagaimana hubungannya dengan huruf - huruf dan kata - kata secara tulisan. Kondisi ini adalah kelainan belajar yang khusus, dan tidak dipengaruhi oleh tingkat inteligensi seseorang. Disleksia adalah masalah yang akan terjadi seumur hidup yang dapat memberikan tantangan pada kehidupan seseorang sehari - harinya. Disleksia muncul pada seseorang atau anak - anak dengan penglihatan atau inteligensi yang normal, terkadang bisa saja tidak terdeteksi selama bertahun - tahun hingga seseorang mencapai usia dewasa. Pada kebanyakan anak yang menyandang disleksia perkembangan kesulitannya muncul pada mengenali kata secara utuh (yang diistilahkan dyseidetic). Sebagian lagi kesulitan dalam mengenali bunyi yang berhubungan dengan huruf (yang diistilahkan dysphonetic).

Gagap melibatkan gangguan pada kemampuan untuk bicara lancer dengan waktu yang tepat. Untuk dapat didiagnosis sebagai gagap, kurangnya kelancaran bicara harus tidak sesuai dengan usia anak. Gagap biasanya dimulai pada usia antara 2 dan 7 tahun. Gangguan ini ditandai oleh satu dari beberapa karakteristik yaitu: 1) Repetisis dari suarasuara dan suku kata, 2) Perpanjangan pada suara- suara tertentu, 3) Penyisipan suara- suara yang tidak tepat, 4) Kata-kata yang terputus, seperti adanya jeda di antara katakata yang diucapkan, 5) Hambatan dalam berbicara, 6) Circumlocution (subtitusi katakata alternatif untuk menghindari kata-kata yang bermasalah), 7) Tampak adanya tekanan fisik ketika mengucapkan kata- kata, dan 8) Repetisi dari kata yang terdiri dari suku kata tunggal (misalnya, "S-s-saya senang bertemu Anda").

Keterlambatan berbicara adalah gangguan berbicara yang bersifat primer, artinya murni karena gangguan perkembangan anak sehingga menyebabkan lambat bicara. Gangguan ini hanya terjadi pada produksi bahasa atau kemampuan ekspresif anak, tidak menghambat penerimaan bahasa atau kemampuan reseptif anak. Mekanismenya tidak diketahui secara jelas, namun penyebabnya adalah faktor genetik. Anak tidak memiliki gangguan retardasi mental, bukan mengalami gangguan sosial dan perilaku, tidak memiliki gangguan pendengaran, serta tidak bermasalah dalam kemampuan reseptif. Bahkan dalam pemeriksaan neurologis sama sekali tidak ditemukan gangguan apapun. Dengan demikian anak tidak boleh mendapat diagnosa apa-apa selain specific language impairment (SLI).

Anak dengan SLI menunjukkan gejala gangguan perkembangan bicara dan bahasa ekspresif yaitu: 1)Mempunyai perkembangan bahasa reseptif yang baik atau normal dibanding dengan kemampuan rata-rata anak seusianya, 2)Mengalami gangguan pada gangguan bahasa ekspresif (secara umum produksi bahasanya lebih rendah daripada kemampuannya memahami bahasa karena mengalami kesulitan menyampaikan pikiran dalam bentuk verbal), 3)Menemui kesulitan dalam komunikasi dialog yang lebih sulit daripada berbicara spontan, sebab komunikasi dialog melibatkan arahan orang lain, 4)Terganggunya kelancaran bicara terutama yang menyangkut pencarian daftar kosa kata dalam memori (finding words), dan kesulitan menyatukan elemen dalam sebuah cerita, 
5)Kesulitan membangun kalimat dan bentuk kata-kata dan 6)Menyampaikan sesuatu dengan menunjuk-nunjuk, menarik-narik, atau dengan suara-suara: aah...uuhh... uuhh...

Pure dysphatic development sebenarnya bukanlah suatu diagnosa, tetapi terminologi yang digunakan bagi sekumpulan gejala atau syndrom dari bentuk speech and language disorder yang nampak secara klinis beberapa saat dalam suatu perkembangan seorang anak sehingga perkembangan itu terlihat tidak normal. Maksudnya bahwa gejala-gejala yang ditampilkan itu tidak akan terdapat pada seorang anak yang normal. Oleh karena itu, jelaslah bahwa anak penyandang SLI tidak mempunyai cacat di otak baik dalam gejala mayor maupun minor. Kebanyakan muncul masalah karena adanya gangguan yang mengikuti atau komorbiditas seperti gangguan motorik dan konsentrasi.

Cerebral Palsy (CP) atau lumpuh otak bukan penyakit namun merupakan kondisi terganggunya fungsi otak dan jaringan syaraf yang mengendalikan gerakan, laju belajar, pendengaran, penglihatan dan kemampuan berpikir. Kerusakan pada otak tersebut terjadi sebelum, selama atau segera sesudah persalinan. Salah satu imbas dari terganggunya fungsi tersebut yaitu gangguan berbicara dengan beragam variasi kesulitannya.

Penyebab CP sampai saat ini belum bisa dipastikan, namun demikian pada beberapa kasus menunjukkan penyebab yaitu: 1)Kelahiran prematur sehingga perkembangan otak belum sempurna, 2)Terjadi hypoxia atau kurangnya suplai oksigen ke otak janin di kandungan, 3)Adanya cacat tulang belakang dan pendarahan di otak, 4)Penyakit yang menyerang ibu saat hamil dan 5)keracunan timbal atau unsur kimia dalam logam dengan kandungan racun yang sangat tinggi.

Anak dengan $\mathrm{CP}$ memiliki masalah komunikasi yang teridentifikasi sejak bayi. Apabila pada umumnya bayi dapat merespon dan bereaksi terhadap stimuli yang diberikan, tidak demikian halnya dengan penyandang $\mathrm{CP}$. Hal ini karena keterbatasan geraknya yang menyebabkan tubuhnya kaku, lemas, lunglai, tidak mampu mengkoordinasikan gerak lengan dan tungkainya, juga menggerakkan otot wicara. Mereka dapat mengalami keterlambatan berbicara, berbicara tidak jelas, dan mengalami sejumlah kesulitan bertutur lainnya. Sebagai gantinya mereka dapat menunjuk pada objek yang dimaksudnya.

Adapun secara intelejensi mereka menunjukkan kemampuan yang beragam. Meskipun sebagian penyandang $\mathrm{CP}$ mengalami keterbelakangan mental, pemahaman mereka sangat potensial untuk dikembangkan. Pada beberapa penyandang $\mathrm{CP}$, pendengaran dan penglihatan tidak berfungsi maksimal. Hal inilah yang menyebabkan timbulnya kesan intelegensinya kurang. Oleh karena itu diperlukan observasi mendalam supaya kesulitan utamanya dapat dientas.

Pada umumnya terdapat beberapa cara menangani gangguan berbahasa pada anak yaitu:

a. Ajak berbicara. Seringkali beberapa orang merasa bahwa mengajak ngobrol atau berbicara anak tidak akan ada gunanya, terutama untuk mereka yang mengalami perkembangan bahasa pada anak. Padahal mengajak anak berbicara jelas menjadi salah satu terapi yang mudah digunakan untuk menghilangkan gangguan perkembangan bahasa. Biasanya ibu dan ayah menjadi panutan ketika mereka berbicara. Usahakan setiap berbicara dengan mereka gunakan ba. hasa yang baik dan tentu saja benar, selain itu gunakan pengucapan yang jelas agar mereka bisa memahami dan mengerti pembicaraan apa yang sudah dilakukan.

b. Bernyanyi. Anak-anak lebih senang jika mereka mendengar musik meskipun mereka belum bisa berbicara. Untuk itu bernyanyi bisa jadi cara yang paling mudah untuk dilakukan dan juga disenangi anakanak. Bernyanyi tidak terasa memaksa pada anak yang mengalami perkembangan khususnya pada bahasa, semua orang tua 
pasti senang menyanyikan berbagai lagu untuk anaknya. Usahakan untuk bernyanyi lagu anak-anak, kemudian jangan lelah mengajak anak untuk ikut mengucapkan meskipun bahasanya belum benar dan masih kesulitan. Hal tersebut bisa menjadi stimulan dan bisa dilakukan dimana saja, nyanyikan secara ceria agar mereka terus mengingat. Bahkan anda bisa mengkombinasikannya dengan film anakanak.

c. Ulang kata yang anak pelajari. Mengulang kata bisa menjadi alternatif mengatasi gangguan bahasa pada anak. Misalnya anak baru bisa mengakan makan atau minum, maka ulangi sekali lagi bahasa yang mereka ucapkan untuk memastikan mengenai usaha mereka. secara tidak langsung hal seperti ini menjadi Metode Assesmen Dalam Psikologi Anak untuk bisa belajar dan terbiasa di uji. Hal seperti ini melatih anak untuk mengatakan bahasa dan kosakata yang benar. Jika rajin maka semakin hari akan semakin banyak meskipun harus melewati proses yang panjang. Biasanya dengan mengulangi kata atau bahasa yang anak pelajari maka anak akan merasa dihargai dan merasa diperhatikan usahanya. Terutama jika maksud yang ia sampaikan bisa kita mengerti dan benar.

d. Terapi. Jika memang masalah perkembangan bahasa anak sudah diketahui maka tidak ada hal yang bisa dipertahankan selain memberikan terapi yang tepat untuk anak. Seringkali beberapa orang menghindari terapi karena mereka gengsi dan tidak menginginkan anaknya seperti bermasalah atau mengalami gangguan. Padahal jika ditunda atau diperlambat yang ada hanya menimbulkan masalah untuk anak-anak dan semakin lama bisa semakin parah. Jika sudah sepert ini siapa yang akan tanggung jawab ataupun menanggungnya? jelas anak kita sendiri yang harus mengalami keburukannya. Hindari gengsi dan periksakan ke dokter, jika memang harus terapi jalani agar perkembangan anak semakin baik.

e. Pemeriksaan rutin. Gangguan perkembangan bahasa pada anak merupakan hal yang terjadi pada beberapa anak, dimana perkembangan mereka tidak terlalu baik dan terkendala karena banyak faktor. Untuk itu anda bisa melakukan pemeriksaan rutin, tujuan utamanya bukan karena orang tua merasa panik jika ada kejadian seperti itu. Sebagian masalah gangguan perkembangan bahasa didasarkan pada alasan yang tidak terlalu menakutkan dan anak-anak mulai bisa belajar bicara. Namun sebagai orang awam ada beberapa hal yang tidak bisa dideteksi dan mengharuskan pemeriksaan lengkap agar bisa mendeteksi masalahnya.

Namun diatas itu semua, hal yang paling utama yang harus dilakukan untuk menangani gangguan berbahasa pada anak adalah sewaktu anak masih dalam kandungan yaitu dengan memberikan nutrisi yang cukup dan tidak mengonsumsi makanan-makanan atau minuman-minuman yang dapat mengganggu kesehatan bagi si ibu dan si anak.

\section{KESIMPULAN}

Dari pembahasan diatas dapat disimpulkan bahwa jenis gangguan bahasa yang terjadi pada anak di kecamatan Pahae Julu adalah gangguan berbahasa yang bersifat spectrum autisme perilaku deficit yang ditandai dengan gangguan bicara, perilaku sosial kurang sesuai (naik ke pangkuan ibu bukan untuk kasih sayang tapi untuk meraih kue), defisit sensoris sehingga dikira tuli, bermain tidak benar dan emosi yang tidak tepat, misalnya tertawa tanpa sebab, menangis tanpa sebab, dan melamun, apraksia lisan, disleksia, gagap, keterlambatan berbicara (speech delay) dan cerebral palsy

Gangguan berbahasa ini terjadi pada anak yang berada di kecamatan Pahae Julu terjadi salah satunya karena faktor genetik atau diturunkan dari orang tuanya karena orang tua dari anak penderita autisme, berisiko memiliki anak dengan gangguan yang sama dan 
penyebab lain adalah nutrisi yang kurang selama dalam kandungan. Ketika seorang ibu mengandung anak tersebut, nutrisi yang masuk kurang bahkan si ibu tersebut sering meminum minuman beralkohol atau yang lainnya sehingga menyebabkan anak yang di kandungnya tersebut berisiko menjadi autis. Sehingga hal yang pertama yang harus dilakukan untuk menangani gangguan berbahasa tersebut pada anak yaitu dengan memberikan nutrisi yang cukup agar si anak tumbuh optimal baik secara fisik maupun psikis.

\section{DAFTAR PUSTAKA}

Natsir. 2017. Hubungan Psikolinguistik dalam Pemerolehan dan Pembelajaran Bahasa. STIA YAPPI:Makassar

Indah. 2017. Gangguan Berbahasa. UIN: Maliki Press

Handoyo, Y. 2004. Autisme: Petunjuk Praktis \& Pedoman Materi untuk Mengajar Anak Normal, Autis dan Prilaku Lain. Jakarta: PT Bhuana Ilmu Populer

Dardjowidjojo, S (Ed.) 1991. Language Neurology: PELBA 4. Jakarta: Lembaga Bahasa Unika Atma Jaya.

Busro. 2016. Kajian dalam Psikolinguistik, Perangkat Penelitian, Strategi, dan Penggunaan Metode Penelitian. AL HIKMAH: Jurnal Studi Keislaman

Simanjuntak. 1987. Pengantar Psikolinguistik Modern. Kuala Lumpur: Kementerian Pelajaran Malaysia

Chaer, A. 2003. Psikolinguistik:Kajian Teoretik. Jakarta: PT Rineka Cipta. 